\title{
Soybean growth and yield under cover crops
}

\author{
Priscila de Oliveira $^{1}$, Adriano Stephan Nascente ${ }^{2}$, João Kluthcouski ${ }^{3}$
}

\begin{abstract}
The use of cover crops in no-tillage systems can provide better conditions for the development of soybean plants with positive effects on grain yield and growth analysis techniques allow researchers to characterize and understand the behavior of soybean plants under different straw covers. Thus, the aim of this study was to characterize, using growth analysis, yield components and agronomic performance of soybean under common bean, Brachiaria brizantha and pearl millet straws. The experiment was performed on a soil under cerrado in the municipality of Santo Antônio de Goiás, GO. The experiment was arranged in a randomized complete block design with three treatments (cover crops) and five replications. Soybean grain yield was lower in the $B$. brizantha straw treatment $\left(3,708 \mathrm{~kg} \mathrm{ha}^{-1}\right)$ than both in the pearl millet $\left(4.772 \mathrm{~kg} \mathrm{ha}^{-1}\right)$ and common bean straw treatments $\left(5,200 \mathrm{~kg} \mathrm{ha}^{-1}\right)$. The soybean growth analysis in $B$. brizantha, pearl millet and common bean allowed characterizing the variation in the production of dry matter of leaves, stems, pods and total and leaf area index that provided different grain yields. The cover crop directly affects the soybean grain yield.
\end{abstract}

Key words: Glycine max (L.) Merr., Phaseolus vulgaris (L.), Pennisetum glaucum (L.) R. Br., Brachiaria brizantha (Hochst. ex A. Rich.) Stapf, no-tillage system.

\section{RESUMO}

\section{Análise de crescimento e produtividade de grãos de soja sobre plantas de cobertura}

O uso de plantas de cobertura no sistema plantio direto pode proporcionar melhores condições para o desenvolvimento da cultura da soja com reflexos positivos na produtividade de grãos, e o uso da técnica de análise de crescimento permitirá caracterizar e entender o comportamento das plantas de soja sobre diferentes palhadas. Dessa forma, o objetivo deste trabalho foi caracterizar, por meio da análise de crescimento, os componentes e o desempenho agronômico da soja sobre as palhadas de feijão-comum, Brachiaria brizantha e milheto. O experimento foi conduzido em solo de cerrado no município de Santo Antônio de Goiás, Estado de Goiás. O delineamento experimental foi o de blocos completos casualizados, com três tratamentos (palhadas de cobertura) e cinco repetições. A produtividade de grãos de soja foi menor sobre palhada de $B$. brizantha $\left(3,708 \mathrm{~kg} \mathrm{ha}^{-1}\right)$ do que sobre as palhadas de milheto $\left(4,772 \mathrm{~kg} \mathrm{ha}^{-1}\right)$ e feijão-comum $\left(5,200 \mathrm{~kg} \mathrm{ha}^{-1}\right)$. A avaliação da análise de crescimento das plantas de soja sobre as palhadas de $B$. brizantha, milheto e feijão-comum possibilitou caracterizar a variação na produção de matéria seca de folhas, hastes, vagens e total e no IAF (índice de área foliar), que proporcionou as diferentes produtividades de grãos da soja. A planta de cobertura afeta diretamente a produtividade de grãos de soja.

Palavras-chave: Glycine max (L.) Merr., Phaseolus vulgaris L., Pennisetum glaucum (L.) R. Br., Brachiaria brizantha (Hochst. ex A. Rich.) Stapf, sistema plantio direto.

\footnotetext{
Received: 23/10/2012;Accepted: 17/01/2013

${ }^{1}$ Agronomist Engineer, Doctor of Science. Embrapa Cerrados, Rodovia BR 020, Km 18, Caixa Postal 08223, 73310-970, Planaltina, Distrito Federal, Brasil. priscila.oliveira@embrapa.br ${ }^{2}$ Agronomist Engineer, Doctor of Science. Embrapa Arroz e Feijão, Rodovia GO-462, Km 12, Zona Rural, Caixa Postal 179, 75375-000, Santo Antônio de Goiás, Goiás, Brasil. adriano.nascente@embrapa.br (corresponding author).

${ }^{3}$ Agronomist Engineer, Doctor of Science. Embrapa Arroz e Feijão, Rodovia GO-462, Km 12, Zona Rural, Caixa Postal 179, 75375-000, Santo Antônio de Goiás, Goiás, Brasil. joão.kluthcouski@embrapa.br
} 


\section{INTRODUCTION}

Soybean is an annual legume native to China, cultivated for centuries in that country and currently is planted in various regions of the world. In 2010, the world produced 265 million tons of soybeans. Brazil comes second behind the U.S. (Faostat, 2012) with a cultivated area of 25 million hectares in 2011/2012, production of about 63.38 million tons and yield of $2651 \mathrm{~kg} \mathrm{ha}^{-1}$ (Conab, 2012). However, despite the importance of the crop, grain yield is still considered low, since there are reports of yield reaching $5000 \mathrm{~kg} \mathrm{ha}^{-1}$ in experimental conditions in the State of Paraná (Hungria et al., 2001).

The expression of the crop yield potential (phenotype) is a function of genotype (cultivar) and environment effects (climate, soil and cultural practices), with emphasis on the supply of nitrogen $(\mathrm{N})$, which is the nutrient most required by the crop (Pires et al., 1998; Rambo et al., 2002; Embrapa, 2006a).

In modern agricultural systems, the no-tillage (or direct planting) is a farming system in which the soil is managed with minimum tillage, previous crop residues are retained on the soil surface and crop rotation is practiced. The use of these practices provides reduced time spent in agricultural operations, increases in soil organic matter, nitrogen and soil biological activity, reduction in soil temperature fluctuations, reduction in sheet erosion, reduction in the amount of fertilizer and pesticides carried into nearby bodies of water and reduction in weed density, while allowing for a greater conservation of soil moisture; it is, therefore, considered a sustainable production system (Nascente et al., 2011; Oliveira et al., 2011; Nascente \& Crusciol, 2012). For these reasons the no-tillage farming system (NT) has been widely adopted worldwide; presently adopted in almost 117 million hectares (Faostat, 2012). In Brazil, since the $1970 \mathrm{~s}$, the NT system has also been expanding, with a cultivated area over 25 million hectares (FEBRAPDP, 2012).

In the no-tillage system, the decomposition of the straw mulch, because of the increase in the levels of organic matter, improves the soil structure and fertility (Padovan et al., 2006). During the process of degradation, the nutrients released can be absorbed by the successor crops, and may have positive effects on their yields (Kluthcouski et al., 2003; Oliveira et al., 2011).

Pearl millet (Pennisetum glaucum (L.) R. Br.) is among the sources of straw mulching that produce large amounts of biomass. It has high drought resistance and promotes nutrient cycling (Kluthcouski et al., 2003; Pacheco et al., 2011; Nascente \& Crusciol, 2012). The use of other perennial forage species for the production of cover cover has also increased.
Species of the genus Brachiaria have been widely used as cover crops because of their deep and vigorous root system, the excellent adaptation to low soil fertility, easy establishment, large biomass production and high persistence in the soil surface (Kluthcouski et al., 2003; Crusciol et al., 2012; Nascente et al., 2012).

In addition, the growth analysis describes the morphological and physiological changes in a plant as a function of time and also evaluates the dry matter accumulation (Falqueto et al., 2009; Concenço et al., 2011). It contains basic information of the crop production and can be performed without the need for sophisticated equipment (Falqueto et al., 2009).

The growth analysis evaluates the amount of biomass produced by the plant and assesses the size of the photosynthetic unit (leaf area), collecting data periodically during the development of leaves, stem, flowers and grains (Benicasa, 2003), making thus possible to evaluate the final growth of the plant as well as the contribution of each organ to its full development (Campos et al., 2008).

The growth analysis can be used in the observations of physiological variables that are positively correlated with grain yield (Santos \& Costa, 1997; Campos et al., 2008), providing information that help monitor the adaptation of the crop to new environments, the interspecific competition, the effects of management systems, as well as productive potential of different cultivars (Antoniazzi \& Deschamps, 2006; Falqueto et al., 2009).

Accordingly, based on the hypothesis that the cover crop species influences the development and, consequently, the soybean grain yield, the aim of this study was to characterize, using the growth analysis, yield components and agronomic performance of soybean grown on common bean, B. brizantha and pearl millet straw.

\section{MATERIAL AND METHODS}

The experiment was conducted in the summer rainfall season of the agricultural year 2007/2008, in the Capivara Farm located in the municipality of Santo Antônio de Goiás, Goiás, $16^{\circ} 28^{\prime} 00^{\prime \prime} \mathrm{S}$ and $49^{\circ} 17^{\prime} 00^{\prime \prime} \mathrm{W}, 823 \mathrm{~m}$ altitude. The climate, according to the Köppen classification, is tropical savanna (AW), mesothermal. The average annual temperature ranges from 20.6 to $23.2^{\circ} \mathrm{C}$, with average rainfall of $1,485 \mathrm{~mm}$. The experimental field had been in no-till (NT) for 1 year and has a history of common bean in the winter 2006; maize $+B$. brizantha intercropp in the summer 2006/2007, and common bean, pearl millet and $B$. brizantha in the winter of 2007 . Each species was grown in one third of the total area allocated to the experiment to provide residue for the soil cover. 
The soil is classified as a clayey Oxisol (Embrapa, 2006b). Before setting up the experiment, soil samples of the layer 0-20 cm were collected for chemical analysis, yielding the following results: $\mathrm{pH}$ (water) 6.1, and levels $\left(\mathrm{cmol}_{\mathrm{c}} \mathrm{dm}^{-3}\right)$ of $2.6 \mathrm{Ca}, 0.9 \mathrm{Mg}, 0.0 \mathrm{Al}$ and 5.1 for $\mathrm{H}+\mathrm{Al}$. Levels in $\mathrm{mg} \mathrm{dm}^{-3}$ of $5.8 \mathrm{P}, 218 \mathrm{~K}, 3.6$ for $\mathrm{Cu}, 4.2$ to $\mathrm{Zn}, 33$ to Fe and 51 to $\mathrm{Mn}$, and organic matter $23 \mathrm{~g} \mathrm{dm}^{-3}$.

The experiment was arranged in a randomized complete block design with three treatments (straw mulches) and five replications. Each plot had a total area of $22.5 \mathrm{~m}^{2}(10$ rows of $5 \mathrm{~m}$ spaced $0.45 \mathrm{~m}$ ), in which half was used for plant collection (second, third, eighth and ninth rows) and half for the evaluation of grain yield and its components (fourth, fifth, sixth and seventh rows). The first and tenth rows and $50 \mathrm{~cm}$ at each side of the plot were considered as border. The straw mulches derived from the cultivation of $B$. brizantha, pearl millet and common bean.

Plants were herbicide-desiccated using $6 \mathrm{~L} \mathrm{ha}^{-1}$ of glyphosate to produce the cover crop residues 15 days before sowing (DBS). The mechanical sowing of soybean cultivar BRS Valiosa RR was carried out on 24/11/2007 at $0.45 \mathrm{~m}$ row spacing and density of 17 seeds $\mathrm{m}^{-1}$. The sowing fertilization was $300 \mathrm{~kg} \mathrm{ha}^{-1}$ of the formulation $\left(\mathrm{N}-\mathrm{P}_{2} \mathrm{O}_{5}\right.$ $\left.\mathrm{K}_{2} \mathrm{O}\right)$ 05-30-15. Soybean seeds were coated with peat based inoculant containing Bradyrhizobium japonicum at a dose of $60 \mathrm{~g} .50 \mathrm{~kg}^{-1}$ seeds (commercial product).

Seedling emergence occurred seven days after sowing. Cultural practices were performed according to the recommendations for the crop (Embrapa, 2006a). Weed control was done at 12 days after emergence (DAE), using $2 \mathrm{~L} \mathrm{ha}^{-1}$ of the herbicide Glyphosate (commercial product) containing $600 \mathrm{~g}$ acid equivalent ha- ${ }^{-1}$. At $72 \mathrm{DAE}$, the fungicide Flutriafol was sprayed to control powdery mildew (Microsphaera diffusa), leaf blight (Cercospora kikuchii), brown spot (Septoria glycines) and Asiansoybean-rust (Phakopsora pachyrhizi) at a dose of $0.4 \mathrm{~L}$ $\mathrm{h}^{-1}$ of the commercial product ( $125 \mathrm{~g} \mathrm{~L}^{-1}$ active ingredient). The products were applied using a manual backpack sprayer with spray volume of $200 \mathrm{~L} \mathrm{ha}^{-1}$.

To evaluate the rate of straw mulch decomposition, samples were taken from all plots at four different times: one day before sowing and at 30,60 and 90 days after sowing. A square frame of $25 \mathrm{~cm}$ side $\left(625 \mathrm{~cm}^{2}\right)$ was used for delimiting the collection area , between the crop rows, with four replicates per plot. The material was dried at 60 ${ }^{\circ} \mathrm{C}$ to constant weight. The dry matter obtained was extrapolated to one hectare.

Mass loss of the straw mulches was determined using the model of Dalal \& Mayer (1986), originally used to simulate the decomposition of soil organic matter:

$Y_{t}=Y_{\varepsilon}+\left(Y_{0}-Y_{\varepsilon}\right) \cdot e^{-k t}$ where:

$Y t=$ mass loss of straw mulch in a given time t;

$Y_{0}=$ mass of straw mulch $\left(\mathrm{kg} \mathrm{ha}^{-1}\right)$ in the initial condition, i.e., one day before sowing;

$Y_{t}=$ mass of straw mulch in the final condition $\left(\mathrm{kg} \mathrm{ha}^{-1}\right)$, i.e., the last sampling at $90 \mathrm{DAE}$; and

$k=$ invariable constant which determines the decomposition rate (calculated by the formula.)

For growth analysis, the samples were taken every seven days, from 20 DAE, with two plants collected per plot. In the laboratory, leaf blades, petioles, main stems and pods were separated. The leaf area reads $\left(\mathrm{cm}^{2}\right)$ were taken by a LI-3000 Area Meter. All plant structures were dried in an oven at $60{ }^{\circ} \mathrm{C}$ to constant weight for determination of dry matter.

The following variables were evaluated: leaf area index (LAI), given by the ratio of leaf area $\left(\mathrm{m}^{2}\right)$ and surface area projected on the ground $\left(\mathrm{m}^{-2}\right)$; crop growth rate (CGR) $(\mathrm{g}$ $\mathrm{m}^{-2}$ days $\left.^{-1}\right)$; total dry matter (TDM) $\left(\mathrm{g} \mathrm{m}^{-2}\right)$; leaf dry matter (LDM) $\left(\mathrm{g} \mathrm{m}^{-2}\right)$; stem dry matter (SDM) $\left(\mathrm{g} \mathrm{m}^{-2}\right)$ and pod dry matter (PDM) $\left(\mathrm{g} \mathrm{m}^{-2}\right)$.

Data of total, stem, leaf and pod dry matter obtained in the field were fitted to a three-parameter sigmoidal model:

$Y_{M S T}=\frac{a}{1+e^{-\left(\frac{c-D A E}{b}\right)}}$

where:

$Y_{M S T}=$ estimated production of dry matter;

$a=$ theoretical maximum dry matter yield $\left(\mathrm{g} \mathrm{m}^{-2}\right)$;

$b=$ slope of the curve;

$c=$ time over which the inflection of the instantaneous crop growth rate (CGR) occurs; and

$D A E=$ time of growth (days after crop emergence - DAE).

The first derivative of equation (2), that is, using the same data, was used to estimate the instantaneous crop growth rate $\left(\mathrm{g} \mathrm{m}^{-2} \mathrm{day}^{-1}\right)$, as in equation (3) :

$$
\frac{\partial Y}{\partial t}=-\left\{\frac{a\left[-\frac{1}{b} \cdot e^{-\left(\frac{c-D A E}{b}\right)}\right]}{\left[1+e^{-\left(\frac{c-D A E}{b}\right)}\right]^{2}}\right\}
$$

The quadratic exponential model was used for the determination of the leaf area index.

$Y_{I A F}=z \cdot e^{\left(a D A E-b D A E^{2}\right)}$

where: 
$Y_{I A F}=$ Estimated leaf area index $\left(\mathrm{m}^{2} \mathrm{~m}^{-2}\right)$;

$z=$ initial value of LAI (first collection);

$a$ and $b=$ empirical parameters; and

$D A E=$ time.

The first derivative of equation (3) was used to estimate the instantaneous rate of LAI increase $\left(\mathrm{m}^{2} \mathrm{~m}^{-2}\right.$ day $\left.^{-1}\right)$, as in equation (5):

$$
\frac{\partial Y}{\partial t}=z \cdot e^{\left(a t-b t^{2}\right) * a-2 b D A E}
$$

The soybean was harvested on $07 / 05 / 2008$ by manual uprooting and subsequent threshing of plants using a cereal BC 80 III Nux thresher machine. The following variables were analyzed at harvest: plant stand (number), plant height $(\mathrm{cm}$, with a ruler), pods per plant (number), seeds per pod (number) and 100-seed weight (grams) (adjusted to moisture of $130 \mathrm{~g} \mathrm{~kg}^{-1}$, wet basis). For these evaluations, 20 plants were collected at random within each plot.

The experimental data on grain yield and its production components were analized using the SAS software for analysis of variance and the mean comparison Tukey test at $5 \%$ probability. Mathematical models were processed with the statistical software R (2005), version 2.7.2, package nlme, function nls.

\section{RESULTS AND DISCUSSION}

The straw mulch decomposition was similar regarding the rates of mass loss of the straw mulches: $0.25 \mathrm{mg} \mathrm{m}^{-2} \mathrm{day}^{-}$ ${ }^{1}$ for B. brizantha, $0.23 \mathrm{mg} \mathrm{m}^{-2} \mathrm{day}^{-1}$ for pearl millet and 0.20 $\mathrm{mg} \mathrm{m}^{-2}$ day $^{-1}$ for common bean (Figure 1). Within 90 days, there was decomposition of approximately $50 \%$ of the initial

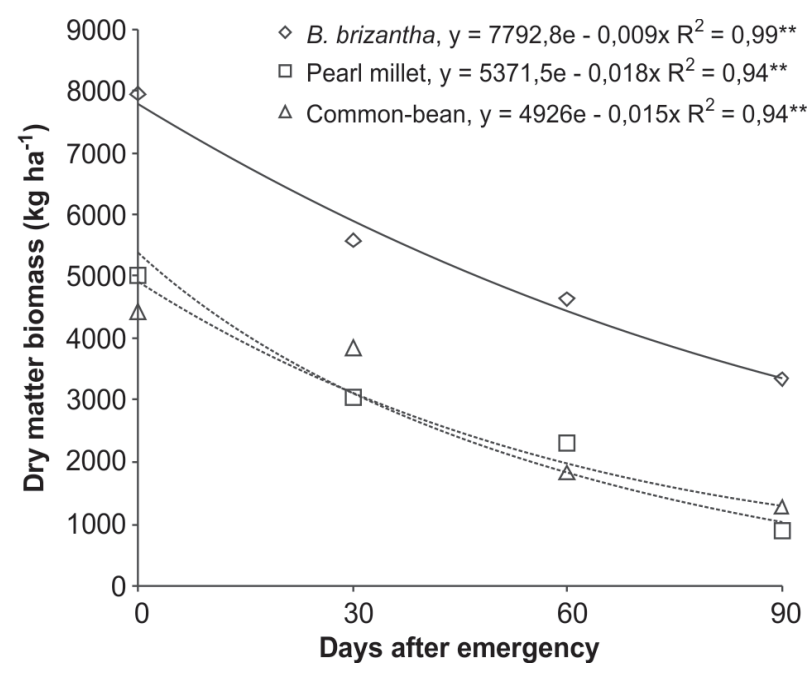

Figure 1. Decomposition of Brachiaria brizantha, pearl millet and common bean straw mulches as a function of days after soybean planting.
B. brizantha straw, $60 \%$ of the pearl millet straw and $70 \%$ of the common bean straw. Pacheco et al. (2011) and Nascente \& Crusciol (2012) also reported that pearl millet had rapid degradation after management desiccation, with reduction in dry weight between 50 and $70 \%$ in the same period. Thus, many factors affect the straw degradation, such as the climate and the straw amount. Accordingly, Braz et al. (2005) reported slower degradation and observed loss of $48 \%$ in the initial dry weight of $B$. brizantha and $58 \%$ in pearl millet, at 150 days. Because the common bean has a lower $\mathrm{C} / \mathrm{N}$ ratio, it also presents a low straw persistence in the soil, while pearl millet and B. brizantha, despite having higher $\mathrm{C} / \mathrm{N}$ ratio than the bean straw, had a faster degradation rate due to the conditions of high temperature and rainfall in tropical regions (Kluthcouski et al., 2003; Oliveira et al., 2011; Pacheco et al., 2011).

The dry matter accumulation of whole soybean plants fitted to a sigmoid curve (Figure 2), which is in agreement with reports by other authors (Campos et al., 2008; Cruz et $a l ., 2010)$. There was an initial phase of slow growth followed by an exponential phase and then a linear growth phase with a new period of slow growth, with the eventual end of the process. In general, annual crop plants, under appropriate conditions of development, have differential biomass accumulation during the various stages of their development: $10-15 \%$ in early development, $60-80 \%$ in the great period of growth (linear phase) and 10-15\% when growth becomes slow again (Lucchesi, 1987; Benicasa, 2003).

Additionally, the soybean plants behaved differently depending on the straw mulch (Figure 2). The highest adjusted total dry mass of soybean straw was recorded for common bean $\left(2200 \mathrm{~g} \mathrm{~m}^{-2}\right)$, followed by pearl millet $\left(1700 \mathrm{~g} \mathrm{~m}^{-2}\right)$ and, lastly, B. brizantha $\left(1300 \mathrm{~g} \mathrm{~m}^{-2}\right)$. In this sense, it can be inferred that the common-bean straw provided the best environment for the development of the plants, such as the faster release of nutrients, including nitrogen, as required by the crop (Pires et al., 1998; Hungria et al., 2001, Rambo et al., 2002; Embrapa, 2006a).

Corroborating this finding, the soybean growth rates under $B$. brizantha straw was the lowest $\left(23.95 \mathrm{~g} \mathrm{~m}^{-2}\right.$ day$\left.{ }^{1}\right)$ at 56 DAE. Under pearl millet straw, the growth rate was $44.23 \mathrm{~g} \mathrm{~m}^{-2}$ day $^{-1}$, peaking at $66 \mathrm{DAE}$, and under common bean straw, $42.72 \mathrm{~g} \mathrm{~m}^{-2}$ day $^{-1}$, peaking at $72 \mathrm{DAE}$.

The leaf growth analysis showed that the dry matter accumulation stabilized around $60 \mathrm{DAE}$, regardless of straw mulch, coinciding with the appearance of flower buds (Figure 2). The growth rate of soybean leaves was the highest under common bean $\left(15.02 \mathrm{~g} \mathrm{~m}^{-2}\right.$ day $\left.^{-1}\right)$, followed by pearl millet $\left(13.88 \mathrm{~g} \mathrm{~m}^{-2} \mathrm{day}^{-1}\right)$ and $B$. brizantha $\left(8.81 \mathrm{~g} \mathrm{~m}^{-2}\right.$ day $\left.^{-1}\right)$, peaking at 52,51 and $50 \mathrm{DAE}$, respectively. The dry matter accumulation in the stems was similar to that of the leaves, with the greatest accumulation occurring until about 70 DAE (Figure 2). 
The growth rate of stems was the lowest under $B$. brizantha straw (10.39 $\mathrm{g} \mathrm{m}^{-2}$ day $\left.^{-1}\right)$, with the highest accumulation occurring in the same period of the plants under pearl millet and common bean straw mulch (59 and $60 \mathrm{DAE})$. The dry matter accumulation of pods was the highest between 80 and 110 DAE (Figure 2).

The highest dry matter accumulation in leaves occurred at flowering (50-52 DAE), while it was later in stems (59-60 DAE). This behavior is explained by the fact that the plant prioritizes the production of leaves for the production of assimilates; having subsequently the need to sustain future fruits the plant will accumulate dry matter in the stems (Benicasa, 2003). It is noteworthy that despite the soybean plants still continue to photosynthesize, there was no increase in dry matter of stems and leaves from that period. On the other hand, the dry matter of pods began to show linear growth during this period (60-70 DAE), probably due to the translocation of assimilates from leaves and stems to pods. At the end of the cycle, the participation of the pods in total dry matter was the highest among the structures evaluated.
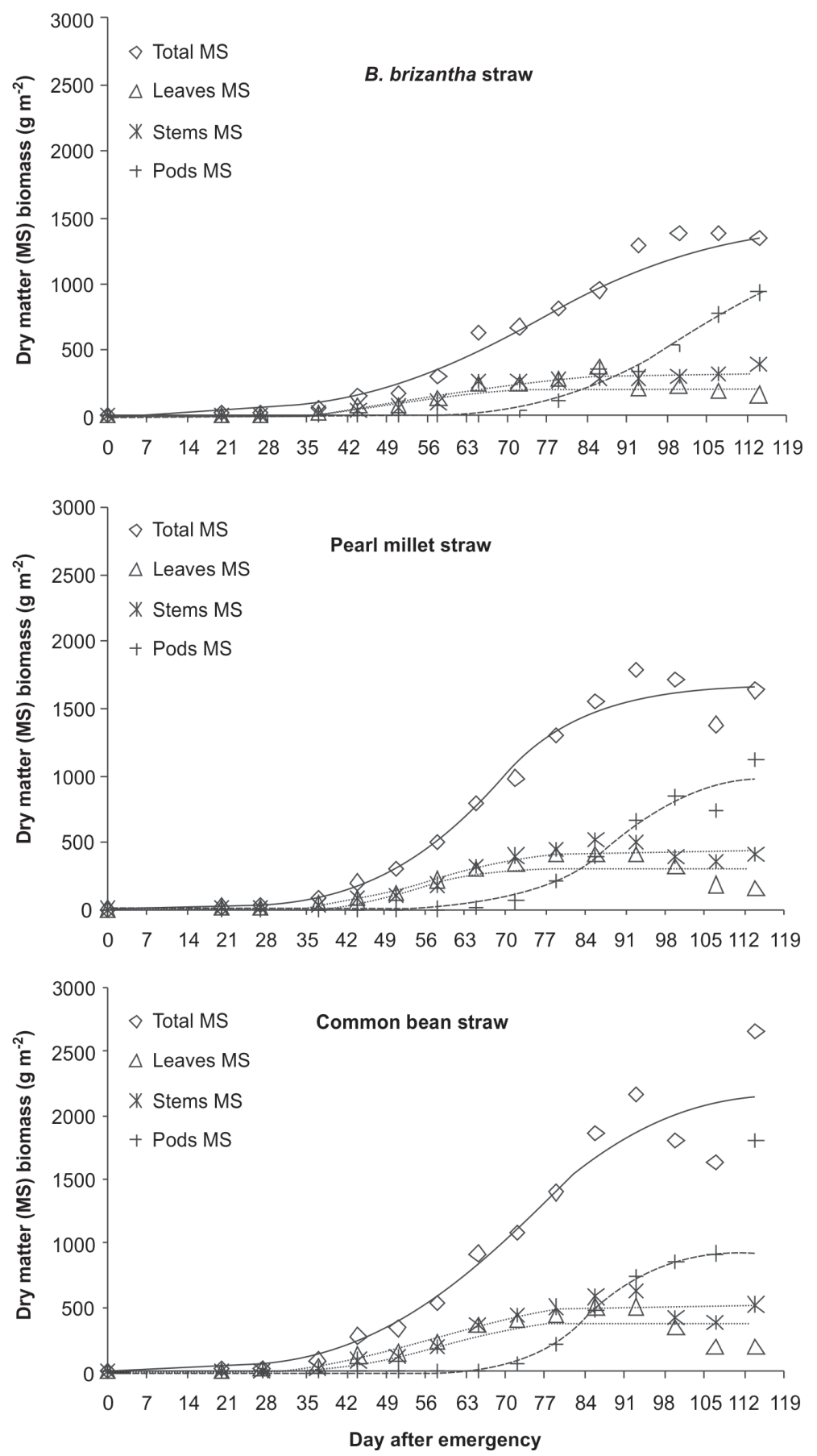

Figure 2. Production of dry matter of whole plant, leaves, stems and pods of soybean grown on Brachiaria brizantha, pearl millet and common bean straw mulches. 
The behavior of individual leaves, stems and pods under different straw mulches was similar to that observed in the accumulation of total dry matter, in which plants grown under common bean straw showed higher dry matter of leaves $\left(160,150\right.$ and $195 \mathrm{~g} \mathrm{~m}^{-2}$ for $B$. brizantha, pearl millet and common bean straw mulches, respectively), stems (380, 407 and $522 \mathrm{~g} \mathrm{~m}^{-2}$ for B. brizantha, pearl millet and common bean straw mulches, respectively) and pods (931, 1118 and $1803 \mathrm{~g} \mathrm{~m}^{-2}$ for B. brizantha, pearl millet and common bean straw mulches, respectively) at the end of the cycle at 114 DAE (Figure 2).

These results reflect the highest growth rates of the plant parts on these straw mulches. In addition, the growth of soybean on common bean straw slightly influenced the development of pods, since they showed the highest growth rate in the shortest time $(86,90$, and 103 days for the common bean, pearl millet and B. brizantha, respectively). Based on these results, it can be inferred that some unidentified factor related to B. brizantha straw promoted the elongation of the soybean cycle.

LAIs were around 14,12 and $9 \mathrm{~m}^{2} \mathrm{~m}^{-2}$ day $^{-1}$ for the common bean, pearl millet and B. brizantha straw mulches, respectively (Figure 3). In general, grain yield increases with LAI if there is no water restriction (Alvarez et al., 2012). The results showed that the common bean straw can provide higher soybean yields. Cobucci \& Portela (2003) cultivated soybean intercropped with B. brizantha, also in Santo Antônio de Goiás, and reported LAI equivalent to $14 \mathrm{~m}^{2} \mathrm{~m}^{-2}$ at 65 DAE. These differences may be caused by the intercropped cultivation, whereas in this experiment soybean was grown as a single crop.

The highest intensity of increase in LAI occurred between 59 and 61 DAE, with values of $0.289,0.371$ and $0.421 \mathrm{~m}^{2} \mathrm{~m}^{-2}$ day $^{-1}$ for $B$. brizantha, pearl millet and common bean straw mulches, respectively. These values also indicate that soybean development was best on common bean straw mulch. After this period, there was reduction in the LAI of all mulches because of the reduction in leaf area caused by plant senescence, death and leaf fall (Campos et al., 2008).

Grain yield of soybean was higher under common bean and pearl millet straw mulches and were not significantly different (Table 1). Almeida et al. (2008) also found no significant difference among yields of soybean grown on pearl millet, sunn hemp, fallow, mucuna and pigeonpea. Our findings show that the soybean crop adapts to different types of straw mulch in the NT system; however, some cover crops can impair the soybean development, resulting in lower yield. In this study, soybean yield on the $B$. brizantha straw mulch was significantly lower and the number of pods per plant was the most affected yield component (Table 1). Likewise, Merlin (2008) reported reduction of grain yield in soybean grown in plots with $B$. brizantha straw mulch $\left(2700 \mathrm{~kg} \mathrm{ha}^{-1}\right)$ compared with the plots without the forage $\left(3300 \mathrm{~kg} \mathrm{ha}^{-1}\right)$.

It is likely that some factor related to B. brizantha straw mulch significantly affected the grain yield of soybeans. One possible explanation would be the Glyphosate management in the cover crops. According to Yamada \& Castro (2007) and Nascente et al. (2012; 2013), the systemic nature of Glyphosate causes plants to take longer to completely dry, and in the case of large areas of cover crop desiccation, it may happen that at the sowing time there are erect plants not still completely desiccated that can cause initial shading, etiolation, yellowing of seedlings, reduced development, increased susceptibility to competition with weeds and decrease in grain yield.

Plants of the genus Brachiaria take longer to be completely dried out, and the herbicide can be remobilized and translocated to non-target plants. According to Monquero et al. (2010), pearl millet plants were completely desiccated after seven days of the Glyphosate application, but $B$. brizantha took more than 20 days. Several research papers recommended a range of two to three weeks

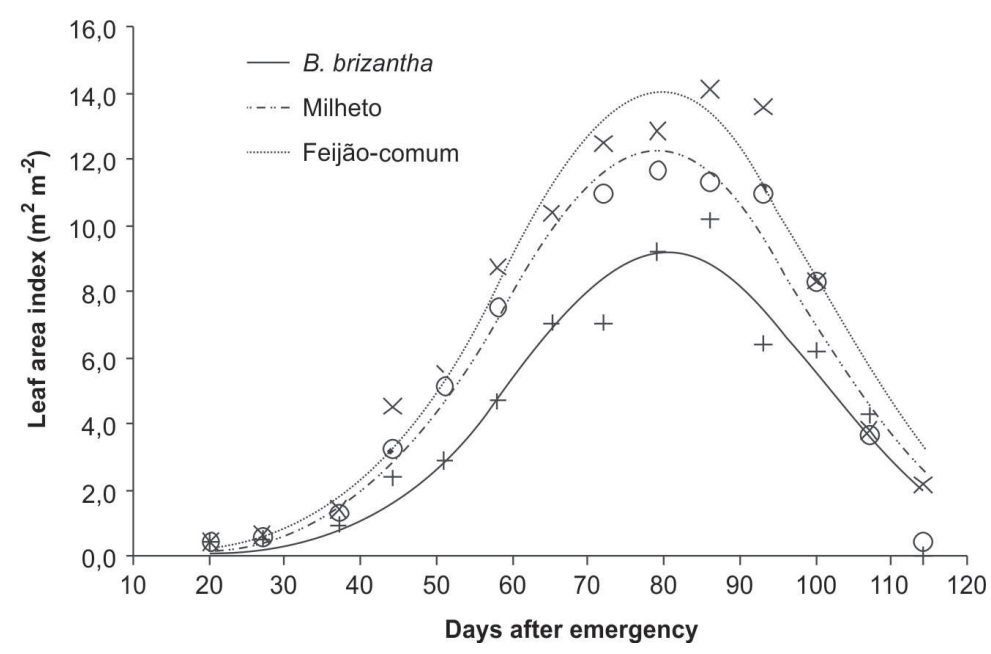

Figure 3. Leaf area index (LAI) of soybean grown on Brachiaria brizantha, pearl millet and common bean straw mulches. 
Table 1. Mean yield components and grain yield of soybean grown on three cover crop mulches

\begin{tabular}{lccccc}
\hline Straw mulch & $\begin{array}{c}\text { Stand } \\
\left(\text { plant } \mathbf{~ m}^{-1}\right)\end{array}$ & $\begin{array}{c}\text { Pods/plant } \\
(\mathbf{n o} .)\end{array}$ & $\begin{array}{c}\text { Seeds/pod } \\
(\mathbf{n o})\end{array}$ & $\begin{array}{c}\text { 100-seed weight } \\
(\text { grams) }\end{array}$ & $\begin{array}{c}\text { Yield } \\
\left(\mathbf{k g ~ h a}^{-1}\right)\end{array}$ \\
\hline Brachiaria brizantha & $11 \mathrm{a}^{*}$ & $56.8 \mathrm{~b}$ & $2.17 \mathrm{a}$ & $17.8 \mathrm{a}$ & $3,708 \mathrm{~b}$ \\
Pearl millet & $11 \mathrm{a}$ & $67.8 \mathrm{~b}$ & $2.20 \mathrm{a}$ & $21.7 \mathrm{a}$ & $4,772 \mathrm{a}$ \\
Common bean & $10 \mathrm{a}$ & $103.2 \mathrm{a}$ & $2.12 \mathrm{a}$ & $19.2 \mathrm{a}$ & $5,200 \mathrm{a}$ \\
LSD $^{+}$ & 2.0 & 30.4 & 0.08 & 3.6 & 876 \\
\hline $\mathrm{CV}(\%)$ & 10.3 & 20.3 & 1.9 & 11.0 & 9.7 \\
\hline
\end{tabular}

* Means followed by the same small letter in the column are not significantly different at 5\% probability by the Tukey test.

+ LSD: least significant difference.

between applying glyphosate and soybean sowing (Peixoto \& Souza, 2002; Constantin \& Oliveira Junior, 2005; Embrapa, 2006a; Santos et al., 2007; Nunes et al., 2009; Monquero et al., 2010; Nascente \& Crusciol, 2012).

However, it is noteworthy that the correct management of herbicide can provide significant increases in grain yield of soybean. Broch et al. (1997) and Pitol et al. (2001) reported soybean yields on $B$. brizantha straw mulch higher than the fallow treatments. Nascente \& Crusciol (2012) found that soybean yield did not differ among crops grown on five species of cover crops (B. brizantha, $B$. ruziziensis, Panicum maximum, Pennisetum glaucum) and fallow. Yamada \& Castro (2007) and Nascente et al. (2013) discussed that the improper use of Glyphosate can cause phytotoxicity or even death to plants of economic interest, requiring therefore the correct management. The chemical desiccation of the cover plants at the right time is recommended in order to achieve the desired results.

The common bean and pearl millet straw mulches provided good conditions for the development of the soybean crop, with positive effects on grain yield. Furthermore, the analysis of growth rates showed higher dry matter accumulation of the whole plant, leaves, stems and pods and higher LAI when soybean was grown on these mulches, which is the likely cause of these higher grain yields, corroborating information from other authors (Santos \& Costa, 1997; Antoniazzi \& Deschamps, 2006; Campos et al., 2008).

\section{CONCLUSIONS}

The common bean straw mulch provided the highest yield of soybean, whereas $B$. brizantha the lowest yield.

The growth analysis of soybean grown on the $B$. brizantha, pearl millet and common bean straw mulches allowed us to characterize the variation in dry matter production of leaves, stems, pods and whole plant, as well as the LAI that provided different grain yields of soybean.

The cover crop directly affects the productivity of the soybean crop.

\section{REFERENCES}

Almeida VP, Alves MC, Silva EC \& Oliveira SA (2008) Rotação de culturas e propriedades físicas e químicas em Latossolo Vermelho de cerrado sob preparo convencional e semeadura direta em adoção. Revista Brasileira de Ciência do Solo, 32:1227-1237.

Alvarez RCF, Crusciol CAC \& Nascente AS (2012) Análise de crescimento e produtividade de cultivares de arroz de terras altas dos tipos tradicional, intermediário e moderno. Pesquisa Agropecuaria Tropical, 42:397-406.

Antoniazzi N \& Deschamps C (2006) Análise de crescimento de duas cultivares de cevada após tratamentos com elicitores e fungicidas. Ciência Rural, 36:1065-1071.

Benicasa MMP (2003) Análise de crescimento de plantas: Noções básicas. 2a ed. Jaboticabal, Funep. 41p.

Braz AJBP, Kliemann HJ \& Silveira PM (2005) Produção de fitomassa de espécies de cobertura em Latossolo Vermelho distroférrico. Pesquisa Agropecuária Tropical, 35:55-64.

Broch DL, Pittol C \& Borges EP (1997) Integração agriculturapecuária: Plantio direto da soja sobre pastagem na integração agropecuária. Maracaju, Fundação MS. 24p.

Campos MF, Ono EO, Boaro CSF \& Rodrigues JD (2008) Análise de crescimento em plantas de soja tratadas com substâncias reguladoras. Revista Biotemas, 21:53-63.

Cobucci T \& Portela CM (2003) Manejo de herbicidas no Sistema Santa Fé e na braquiária como fonte de cobertura morta. In: Kluthcouski J, Stone LF \& Aidar H (Eds.) Integração lavourapecuária. Santo Antônio de Goiás, Embrapa Arroz e Feijão, p.443-458.

Conab - Companhia Nacional de Abastecimento (2012) Levantamento da produção de grãos - safra 2010/11. Avaiable at: <www.conab.gov.br>. Accessed on February 25, 2102.

Concenço GI, Aspiazú I, Galon L, Ferreira EA, Freitas MAMV, Fialho CMTV, Schwanke AMLV, Ferreira FAV \& Silva AA (2011) Photosynthetic characteristics of hybrid and conventional rice plants as a function of plant competition. Planta Daninha, 29:803-809.

Constantin J \& Oliveira Júnior RS (2005) Dessecação antecedendo a semeadura direta pode afetar a produtividade. Informações Agronômicas, 109:14-15.

Crusciol CAC, Mateus GP, Nascente AS, Martins PO, Borghi E \& Pariz CM (2012) An innovative crop-forage intercrop system: early cycle soybean cultivars and palisadegrass. Agronomy Journal, 104:1085-1095.

Cruz TV, Peixoto CP \& MC Martins (2010) Crescimento e produtividade de soja em diferentes épocas de semeadura no oeste da Bahia. Scientia Agraria, 11:33-42. 
Dalal RC \& Mayer RJ (1986) Long-term trends in fertility of soils under continuous cultivation and cereal cropping in Southern Queensland. II. Total organic carbon and its rate of loss from the soil profile. Australian Journal of Soil Research, 24:281-292.

Embrapa - Empresa Brasileira de Pesquisa Agropecuária (2006a) Centro Nacional de Pesquisa de Soja. Tecnologias de produção de soja. Londrina. 217p.

Embrapa - Empresa Brasileira de Pesquisa Agropecuária (2006b) Centro Nacional de Pesquisa de Solos. Sistema brasileiro de classificação de solos. 2a ed. Rio de Janeiro, Embrapa Solos. 306p.

Falqueto AR, Cassol D, Magalhães Júnior AM, Oliveira AC \& Bacarin MA (2009) Crescimento e partição de assimilados em cultivares de arroz diferindo no potencial de produtividade de grãos. Bragantia, 68: 453-461.

Faostat (2012) Production: Crops. Avaiable at: <www.faostat.fao.org>. Accessed on: March 29, 2012.

Febrapdp - Federação Brasileira de Plantio Direto na Palha (2012) Evolução do plantio direto no Brasil. Avaiable at: <http:// www.febrapdp.org.br/arquivos/EvolucaoAreaPDBr72A06.pdf > Accessed on: March 31, 2012.

Hungria M, Campo RJ \& Mendes IC (2001) Fixação biológica do nitrogênio na cultura da soja. Londrina, Embrapa Soja. 48p. (Circular Técnica, 35).

Kluthcouski J, Stone LF \& Aidar H (2003) Integração lavourapecuária. Santo Antônio de Goiás, Embrapa Arroz e Feijão. 570p.

Lucchesi AA (1987) Fatores da produção vegetal. In: Castro PRC, Ferreira SO \& Yamada T (Eds.) Ecofisiologia da produção agrícola. Piracicaba, Associação Brasileira para Pesquisa da Potassa e do Fosfato. p.1-11.

Merlin A (2008) Disponibilidade de fósforo para a soja cultivada sobre braquiária. Dissertação de Mestrado. Faculdade de Ciências Agronômicas, Universidade Estadual Paulista "Júlio de Mesquita Filho", Botucatu, 95p.

Monquero PA, Milan B, Silva PC \& Hirata ACS (2010) Intervalo de dessecação de espécies de cobertura do solo antecedendo a semeadura da soja. Planta Daninha, 28:561-573.

Nascente AS \& Crusciol CAC (2012) Cover crops and herbicide timing management on soybean yield under no-tillage system. Pesquisa Agropecuária Brasileira, 47:187-192.

Nascente AS, Crusciol CAC, Stone LF \& Cobucci T (2013) Upland rice yield as affected by previous summer crop rotation (soybean or upland rice) and glyphosate management on cover crops. Planta Daninha, 31:147-155.

Nascente AS, Guimarães CM, Cobucci T \& Crusciol CAC (2012) Brachiaria ruziziensis and herbicide on yield of upland rice. Planta Daninha, 30:729-735.
Nascente AS, Kluthcouski J, Rabelo RR, Oliveira P, Cobucci T \& Crusciol CAC (2011) Desenvolvimento e produtividade de cultivares de arroz de terras altas em função do manejo do solo. Pesquisa Agropecuária Tropical, 41:186-192.

Nunes AS, Timossi PC, Pavani MCMD \& Alves PLCA (2009) Épocas de manejo químico de Brachiaria decumbens antecedendo o plantio direto de soja. Planta Daninha, 27:297-302.

Oliveira P, Kluthcouski J, Favarin JL \& Santos DC (2011) Consórcio de milho com braquiária e guandu-anão em sistema de dessecação parcial. Pesquisa Agropecuária Brasileira, 46:11841192.

Pacheco LP, Leandro WM, Machado PLOA, Assis RL, Cobucci T, Madari BE \& Petter FA (2011) Produção de fitomassa e acúmulo e liberação de nutrientes por plantas de cobertura na safrinha. Pesquisa Agropecuária Brasileira, 46:17-25.

Padovan MP, Almeida DL, Guerra JGM, Ribeiro RLD, Oliveira FL, Santos LA, Alves BJR \& Souto SM (2006) Decomposition and nutrient release from soybean cut at different growth stages. Pesquisa Agropecuária Brasileira, 41:667-672.

Peixoto MF \& Souza IF (2002) Efeitos de doses de imazamox e densidades de sorgo (Sorghum bicolor (L.) Moench) em soja (Glycine $\max$ (L.) Merr.) sob plantio direto. Ciência e Agrotecnologia, 26:252-258.

Pires JL, Costa JÁ \& Thomas AL (1998) Rendimento de grãos de soja influenciado pelo arranjo de plantas e níveis de adubação. Pesquisa Agropecuária Gaúcha, 4:183-188.

Pitol C, Gomes EL \& Erbes EI (2001) Avaliação de cultivares de soja em plantio direto sobre braquiárias. In: Fudação MS. Resultados de pesquisa e experimentação-Safra 2000/2001. Maracaju, Fundação MS. p.40-48

Rambo L, Costa JA, Pires JLF, Parcianello G \& Saggin KD (2002) Análise de crescimento e rendimento por estrato do dossel da soja em função do arranjo de plantas. Pesquisa Agropecuária Gaúcha, 8:111-120.

Santos AB \& Costa JD (1997) Crescimento de arroz de sequeiro em diferentes populações e irrigação suplementar. Pesquisa Agropecuária Brasileira, 32:591-599.

Santos JB, Santos EA, Fialho CMT, Silva AA \& Freitas MAM (2007) Época de dessecação anterior à semeadura sobre o desenvolvimento da soja resistente ao Glyphosate. Planta Daninha, 25:869-875.

Yamada T \& Castro PRC (2007) Efeitos do Glyphosate nas plantas: Implicações fisiológicas e agronômicas. Informações Agronômicas, 119:1-32. 